\title{
脊推動物における睪丸組織內脂質顆粒の移動と 量的変化の研究
}

\author{
西田隆雄 \\ （浪速头学教育学部生物学教室）
}

Studies on the migration and the quantitative changes of the

libid granules in testicular tissues of vertebrates

TAKAO NISHIDA

(Department of Biology, Naniwa University.)

\section{緒}

SERTOLI 氏細胞の機能については, 支柱, 栄養および 内分泌の三つの作用があると考えられてきたが，最近 ElftmanN は SERTORI 氏細胞は 週期から内分泌の支配 を受けるとし，HUGGINs and MOOLDER は鋅丸腫愊の場 合には SERTOLI 氏細胞が Estrogen を生産するとし, HOWARD 扣よびその共同研究者らは SERTOLI 氏細胞の ' $\mathrm{x}$ 'ホルモン分泌を推定し，その傍証の一つとして細胞 基底に鳘積せられる類脂質顆粒の存在をあげている。ま た Montagna and Hamilton は:不飽和ステロイドの証 明はホルモン或はその前体の存在を示するのと考えた。 一方古くから睪丸組織内脂質は精子形成に伴つて消長す ることより SERTOLI 氏細胞が栄荃および内分泌の両作 用に関与すると推定されてきた。丹羽および伊藤の豚睪 丸組織内脂買の年龄的差異に関する研究とPERLMANの睪 丸組織内コレステロールに関する実験的研究があるが筆 者? 亦既に大黒鼠精細管内脂質顆粒の出現時期が好気解 糖能の最高を示めす龄 40 日に一致すること, 扣よび睪

$$
\text { 䘚 } \quad 1
$$

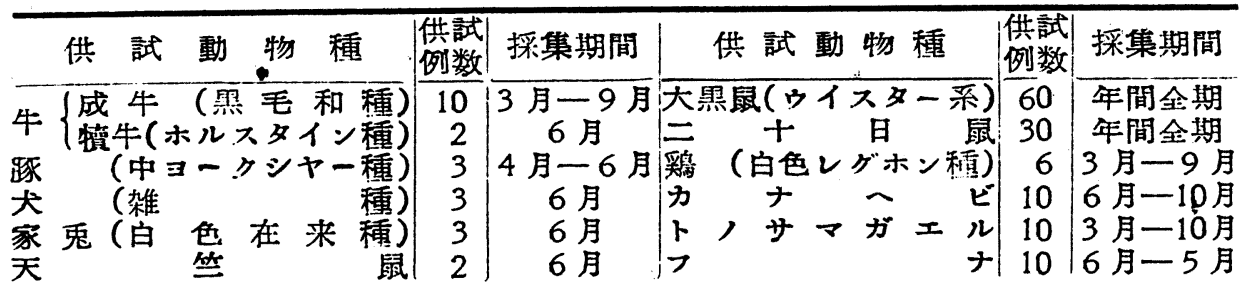

衣 2 大黑鼠の精細管内脂質顆粒の消長

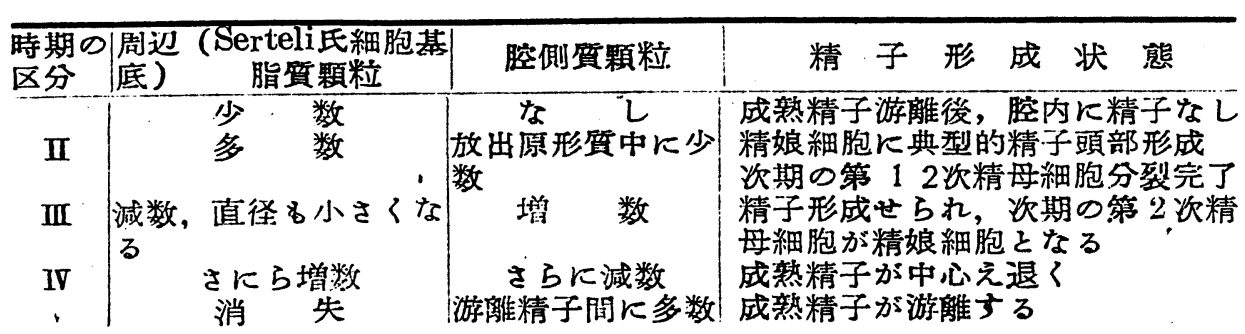

丸組織内脂質の性状に関する実験的, 細胞化学的研究を 報告した。今回は春推動物各綱の材料を用いて睪丸組織 内脂睤を锶察した結果を報告する。

\section{材料および方法}

供試動物の種類，例数および採集時期は表 1 に示す。 殺処分後速かに睪丸を剔出, 所要材料を採取し次のよ ろに処理した。

（1）一般組織像の検查には BooIn 氏液および ZenkerFomol 液で固定しパラフイン切片を作り, 一マトキシ リン，エオシン重染色を施した。SERTOLI 氏細胞の形態 を明らかにするためには青山氏および DA FANO 氏鍍銀 標本を用いた。

（2）脂質の検査には $10 \%$ \%ルマリン固定スダン III 染 色法, Craccio 氏類脂質染色法および HELLY 氏液を用 いてオスミゥム酸による黑化を試み，このほかに組織强 を作り，血清，タイロード氏液扣よびッンガー氏液を媒 圈とし $0.1 \%$ 中性赤扰よび $0.1 \%$ \%イル青による超生 体染色を行つた。

（3）大黒圂につつては一般組織 像の観察に MAXIMAW氏液固定 標本を加え，脂貿顆粒の位置を 確めるためには HELLY 氏液, ILEVI 氏液， Flemming E強夜 および CHAMPY E液固定標本 を加えた。また単一に分離した 精細管を HELLY E液固定後, 厚さ $5 \mu$ のハララフイン連続切片 とし観察および計測を行つた。 SERTOLI 氏細胞は固定時に著し く収維するから，比較のために 分樆精細管の生体観察を任せ行 つた。大黒国睪丸よっ分離した 
精細管を因1に示すような戴せ硝子の湌に投じ被い硝子 をして，一端よりピペットで媒圈を注入し，他端に濾紙 をあて常に媒圈を更新しつ」観察した。媒圈は上記の超 生体染色に用いたものと同じである。

\section{観察結果}

(1) 大黒鼠 HeLLY 氏液を用いてのオスミウム酸によ る黒化とスダンIII染色の結果とは殆んど同じである。一 般組織固定には前者が摘するためこの方法により脂質顆 粒の位置怙よびその直径について観察站びに計測を行つ て表 2 によめた。前期精子形成完了後, 本期 精娘細 胞の棪濃縮の始る頃に精細管周辺部の SERTOLI 氏細胞 基底部に脂質顆粒が出現しはじめ，しだいに大きくなり また数がふえる。精娘細胞に典型的精子顽部の形成せら れる頃には，SERTOLI 氏細胞基底部の脂賣顆粒は著しく 増加し, 次期第 1，2次精母細胞分裂完了まで々の数量 は精子形成全期中最大を示す。その直径は0.5〜 $5 \mu$ で精 子形成の進行とともに数量は減じ，精子の游離とともに やがて消失する。腔側脂質顆粒は直径約 $1 \mu$ で稀に単一 に存するが大部分は集合してブドゥ房状の集塊を形成す る。その増減は周辺脂質顆粒の增減々逆行する。すなわ ちSERTOLI 氏細胞基底部脂質顆粒量の最大をしめる頃 に出現しはじめ成熟精子の腔側への退行期から游離期に かけて，その数量は最大に達する。この腔側脂質顆粒 は，精娘細胞からの放出原形質塊中にあるが，これらは SERTOLI氏細胞原形買突起の外であるか否かは, SERTOLI 氏細胞細胞膜の観察が困難なため沃定することはできな いが細胞外にあると考えうる。分離棈細管を通常扣よび 位相差顕版鏡で観察すれば，固定標本の場合と同じブド ウ房状集塊が認められ媒圈の移動扣よび被い硝子上から の埾い指圧により容易に移動し細胞外にあるという推定 に有利であるが確定的なるのではない。また青山氏鍍銀 標本によれば SERTOLI 氏細胞腔側端に脂質顆粒のブド ウ房状集塊と推定せられるもの拉よび無数の微細顆粒が 羿められる。しかし著者は精細管を組織小板とし同方法 によつて鍍銀した場合に人為産物として同じょうな微細 顆粒の生ずることを確めているので本標本にみられる所 見の一部は信ずることはできないと考える。

SERTOLI 氏細胞基底部脂質顆粒はスダンIII染色および オスミウム酸による黒化の場合には中心部の染色性扣よ び黒化度の低い傾向をもつた球体として罄められるが， CIACCIO 氏法によれば，その形は著しく変化し複踓な像 を作る。FLEMMING 氏強液固定でば,この脂質顆粒が直径 を著しく增した場合に核は基定膜側に圧迫せられ変形す るのを㴓めることがある。ナイル青超生体染色を施せば，
SERTOLI 氏細胞菱底部拉よび腔側の両脂質顆粒は之もに 青くそまる。中性赤では小脂質顆粒のみが赤くそまる。 前記の方法によつて分傩精細管を観察すれば焦点の移動 により大小脂質顆粒が SERToL 氏細胞基底部より腔側に 向つて分布するのが容易に観察される。ついでこの細精 管を位相差顕微鏡の強㹡大で観察すれば D.M., D.L.， では大脂啠顆粒は光り輝き，小脂買顆粒は曋く見え， B.M. では耐者ともに光り輝いてみえる。

これら脂質顆粒の精子形成に伴了消長をさらに具体的 に示すために成熟大黒鼠等丸から長さ $30 \mathrm{~mm}$ に達する 精細管を単一に分離し，前記の方法により連続切片とし 次の観察記録をえた。1期は $` 50 \mu ， 2$ 期は $6100 \mu, 3$ 期は $1200 \mu ， 4$ 期は 4350 めた。間質の発達は著しく悪く, そのために間質内脂質 の量は少い。しかし間細胞な゙どには直径約 $1 \mu$ の脂質顆 粒がかなり含まれ，スダンIII, ナイル青の染色性拉よび オスミウム酸による黑化度は SERTOLT氏細胞基底部脂睤 顆粒とほとんど差がない。

（2）牛 SERTOLI 跑細胞基底側脂質顆粒は大黒鼠と異 なり直径約 $1 \mu$ の小脂質顆粒が多く，3～6 $\mu$ に達する集 塊を作る場合がある。これに比し大脂質顆粒は少い。乙 たがつて脂質顆粒は桷漫性に存し，かなり腔側に伸び， 大黒鼠のように基底部に存するとは云い難い。腔側脂質 顆粒の位置は大黒鼠と同じであるが，特異なブドゥ房状 集塊は作らず,単離するか,あるいは集合して雲桨集塊を 作る。精子形成に伴了消長は大黒鼠に於ける分期と一致 するが，全期間を通じ SERTOLI氏細胞基底部脂質顆粒の 消失することがなく，5期にもかなり多量の大小脂質顆 粒力残つている。3期の脂诈顆粒分布の1例を示せば，基 底膜を底とし腔側へ紡銛状にのび精子頭部に至る約 $45 \mu$ の間には㫌漫性に大脂翼顆粒が分布する。 SERTOLI氏細 胞先端に附着する精子の頭頸部附近, 約 $18 \mu$ の間には 脂質顆粒はなく, 中片部より腔側一約 $36 \mu$ の間には微 小脂質顆粒が多数みられる。これら脂質顆粒の超生体染 色の結果は大黒鼠と同じである。

間質の脂質顆粒の量は大黒鼠拉よび脈などより多く， 間細胞などの細胞内脂質顆粒は直径約 $1 \mu$ 以下のものが 多い。ときには 1.5〜 $2 \mu$ に達するものがある。細胞間 にも直径約 $1 \mu$ の脂質顆粒が認められる。生後 1 週間以

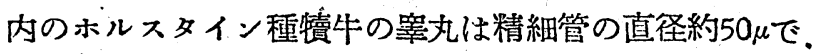
脂貎顆粒は認められない。しかし間質はよく発達し, 間 細胞には多量の脂質顆粒が含をれている。

（3）豚 SERTOLI 氏細胞基底側脂啠顆粒は大小脂質顆 粒よりなるが, 特に大脂質顆粒は㥛めてよく発達し, 直 径約 $7 \sim 10 \mu$ に達する。完全な球体を示するのは少く， 一側をるいは中心の奴けた不整形を示す。スダン望染色 
では，球体周緑より中心部に向つて顕著な染色性の減退 が認められる。オスミウム酸により黒化せしめれば，大 脂質顆粒全体が灰黑色を呈し, 周縁部に真黑色に黒化せ られた直径約 $1 \mu$ 小脂缶顆粒がー列あるいは重複して排 列している。稀に球体中心部にも同じ小脂質顆粒を認め る。大脂質顆粒全体が真黑色に黒化せられた場合でも， その球体の外縁には小脂質顆粒が排列すると見られる複 雑な線を示す。腔側脂質顆粒は直径約 $1 \mu$ で単離するも のが多く，連鎖してジスズ状，あるいは集合して雲状を 呈するものもある。腔側脂質顆释と SERTOLI氏細胞内脂 質顆粒とは著しく接近し，僅かに精子頭部を境として区 別せられるのみである。精子形成波に伴う消長は略々大 黒国のそれに一致するが牛と同じくSERTOLI氏細脂基底 側脂質顆粒の消失期は浔められない。生鮮材料を組織㴽 としナイル青で染めると特巽大脂質顆粒はすべて完全な 球体であり青く染まる。しかし 10\% Formol 固定, 水 結切片とし $0.1 \%$ ナイル青で染色後，1\%醌酸で分別し グリセリンで封ずれば，正球体を示するのは稀で中心部 の染色性を欠くもの，一側の欠けた三日月状，マガタマ 状を示すものが大部分を占める。間啠は一ように淡黄赤 色に染まるが可染脂質顆粒は認められない。

（4）犬 SERTOLI 氏細胞基底側脂質顆粒は大黒臼に類 似し直径 $1 \sim 5 \mu$ の大小脂質顆粒がある。大脂質顆粒中 には正球体を示さずダルマ状を是するのがある。腟側脂 質顆粒は直径 0.8 ～ $1 \mu$ でほとんど単離するが数ケ集つ て集塊を作るのもある。この分布域と量は供試哹類中 では最高を示し, 直径約 $235 \mu$ の精細管で $190 \mu$ の分布 域を占める。 SERTOLI 氏細胞基底側脂質顆粒が 5 期で 消失するのは大黒鼠と同じであるが，1期でもほとんど 存在しない。

間質に於ける脂質量は極めて多く，他の哺乳類と比較 できない。細胞内脂質顆粒は豚の SERTOLI氏細胞基底側 の特異大脂翼顆粒に似て，中央のぬけた輪状のもの三日 月状のものなど種々の不整球体でこの傾向は小脂質顆粒 にもあらわれ，また細胞質は脂質顆粒で满たされる。

（5）家乘 SERTOLI氏細基底部脂質顆粒は牛と同でく源 漫性に分布するが腔倒に拡がらず，直径約 $1 \mu$ の小脂質 顆粒が基底部にみちる。大脂質顆粒扣よび小脂質顆粒の 集塊はない。腔側脂質顆粒は細粉状で直径約 $0.2 \mu$ で, $0.5 \mu$ をこえるものは翟められない。その量は少く分布 域も狹い。精子形成に伴了消長は大黒鼠に一致するが， SERTOLI 氏細胞基部脂質顆粒の消失期はない。間質には 多数の直径約 $1 \mu$ の小脂質顆粒があり主として間細胞内 に存する。

（6）天筑鼠 SERTOLI 氏細胞基底部脂澌顆粒は小脂質
顆粒のみからなり直径約 $1 \mu$ で腔側に向つて, 精子頭部 まで分布している。腔側脂質顆粒も同じ直径をもち，す べて単離している。精子形成に伴ら消長は家鬼と同じ であるが, 精細管内脂質顆粒の量は, 家鬼よりさらに少 い。間の脂留顆粒々家鬼に比して少いが，一細胞内脂質

・顆粒の量にはほとんぞ差がない。

（7）二十日鼠 脂質顆粒の性状扣よび精子形成に伴了 消長は大黒鼠と同じである。しかし, SERTOLI氏細胞基底 部の小脂質顆粒が多く, や〉家臣に類似し，腔側へ瀮漫 性に広く分布している。胵側脂質顆糔もまたブドゥ房状 集塊以外に単離するものがかなりある。

間質は大黒鼠よりもよく発達してをり, 脂質顆粒の量 も多い。間細胞の含有脂質顆粒量にはほとんど飽和状態 にあるものから微量へと種々な移行型がみられる。

（8）鷄 SERTOLI 氏細胞基底側の脂質顆粒は直径約 1 $\mu$ で大脂質顆粒はない。分布域は牛よりも広く腔側に伸 び, SERTOLI氏細胞の形態乞のものをスダン III可染脂質顆: 粒で示しているようである。腔側脂質顆粒も牛に似てい るが,雲状集塊は作らず単離している。間質は発達してい ないが直径約 $2.5 \mu$ の脂質顆粒を多量にもつている。

精子形成に伴了消長は大黒鼠に㧊ける分期に從らが, それほど明確でない。

（9）カナービ，トノサマガェル爬蠳以下の供試脊 推動物では, 同一細精管でも部位によつて, 精子形成の. 時期を異にする精細胞集団よりなる。SERTOLI 氏細胞は， 精子形成の時期の如何にか〉わらずこの精細胞集団をと らかこむので脂質顆粒もこのような位㯰にある SERTOLI 氏細胞内および包囲された精細胞集団の細胞間に存在 する。脂質顆粒の直径は約 $0.5 \sim 1 \mu$ で単離している。

精細胞間の脂質顆粒が SERTOLI 氏細胞原形質突起内に あるか否かは不明である。精子が成熟し，ある時期に達 すれば，SERTOLI 氏細胞は基底膜側へ退行するために 精 細胞間の脂質顆粒は精子とともに腔内に脱落しその 量は極めて多く, オスミウム酸では灰黒色から真黑色に 黒化せられ，スダン而には橙赤色より赤色に, ナイル青 には淡青色に染色せられ, 中性赤には不染である。間質 の発達は悪いが，大部分の間細胞には多量の脂質顆粒が 含まれる。

(10) フナ 精細胞集団を创囲するように存在する SERTOLI氏細胞内の脂質顆粒は精子の成熟に伴つて腔内に脱 落しない。そのためにその脂質顆粒の量は極めて多量で スダンII染色の場合には細胞の区別が不可能で, 脂質顆 粒そのものが 集積して 精細胞集団を包囲する 観を呈す る。HELLx 氏液を用い，脂質顆粒を黑化せしめた場合 には SERTOLI 氏細胞内に直径約 $1 \mu$ の脂質顆䊀がほと. 
んど鞄和状態に達して存在する。精細胞の成熟に伴い, SERTOLI 氏細胞内脂質顆粒よりなる脂質顆粒尸は菲薄に なり，精子が腔内に游離する直前が最も菲薄である。精 子游離後, 残留精原細胞のみとなつた場合には脂質顆粒 尸は最も厚い。オスミウム酸では真黑色に黒化せられ， スダン亚には真赤色に，ナイル青には淡青色に染まり， 中性赫には染まらない。

\section{考察}

睪丸組織内脂質の精子形成に伴了消長は供試全脊推動 物に認められ，特にこの消長は SE'RTOL氏細胞の能動的 生理活動を最も具体的に示するのの一つであると考えら れる。最近の Montagna and,Hamiuton の報告は注目す ベきものであり，精細胞の成熟に叛う細胞内脂質を詳細 に観察しているが SERTOLI氏細胞内脂質顆粒については 充分な記䉐がない。しかし既に野沢は大黒鼠を用いて精 子形成波を 7 期に分け, 脂質顆粒の移動現象をもこれに 從つて分類し，その消長を極めて具体的に示している。表 2 は野沢の観察結果を補い，脂質顆粒を主体とし，その 消長を5期に分けたものである。4期の精子頭部形成 が完了して後, 精子が腔中心に向了期間に精子の附着す るSERTOLI氏細胞基底部脂質顆粒が淢少することから， この脂質顆粒が，典型的頭部を形成してから後の精細胞 に利用せられると推定しうる。 Maximow は Sertolian syncytium が精細胞を包埋すると記載しているが， ElfTMANN は二十日鼠の睪丸に於ける SERTOLI 氏細胞 週期を鍍銀法を用いて追究し，精子形成の時期によるSERTOLI 氏細胞形態の相違,核の頭著な移動抢よび SERTOLI 氏細胞原形質樹枝状突起が精細胞を创み，精子をとらえ ていることを明らかにした。SBRTOLI 氏細胞の機能が核 の移動にみられるように能動的なものであることはSERTOLI 氏細胞と精子間の物質移行に有利な事実である。し かし從来のように SERTOLI氏細胞の形態が基底膜より腟 側に向い，その先端に精子を支持するとされていた場合 には,この説もなりたつがSERTOL氏細胞原形孟樹枝状突 起が全精細胞を包围することが明らかにされ，をた筆者 はそのミトコンドンアの観察より SERTOL住細胞が精細 胞間隐に向つても原形質突起を出すこ之を悡めているた め, 脂質顆粒が次期の精細胞に対してもある意義をるつ のではないかとも考えられ簡単に气の利用せられる時期 を沃定することはできないが，精子形成に伴了消長と， 燐脂嵔を高率に含むことから. SERTOLI氏細胞内脂質顆粒 は精子形成の栄峜源として, 精細胞に利用せられること は容易に推定しうる。

精子形成波の 1 波長間の脂質顆粒の消長を具体的に示 すために試みた分離精細管の連続切片の観察結果は，精
子形成波と脂質顆粒の消長との相関を量的に表現してい る。さらに精子形成すなわち精子の形態が形成せられて 後, 腔内に游離するまでの期間が1波長の6割以上を占女 ることを示し，從来より精子形成として，その形態形成 の部分のみが注目せられてきたのであるが，むしろこの 成熟期といいるる期間こそ精子の生理学的研究に重要な 意味をもつであろろと考えざるをえない。

大黒鼠のように SERTOLI氏細胞基底部脂質顆粒が大湖 質顆粒を主体とするるのには，二十日鼠，犬および豚力

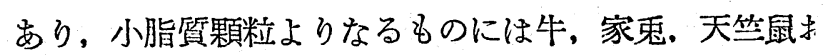
よび鷄がある。犬，天䇥鼠拉よび二十日鼠には大黒鼠。 ように，この脂質顆粒の消失期があるが，牛，豚，家玉 および鶏にはない。このような美晎ば多分, 間質の発言 度，基底膜の構造拉よびそれに伴了代謝源の供給椂式。 美異に基づくものと考えられる。天䇥氮, 大黒鼠およて 二十日鼠 (第 1 群) は, 間質が発達しないが牛，豚，二 扣よび家鬼(第 2 群)は間質がよく発達している。第 1 差 では間質の発達が悪いために次の精子形成初期に必要习. 脂質を得るに一定の期間を必要とし， SERTOLI 氏細胞「 に大脂質顆粒として畒積しなければならない。第 2 群一 は間質がよく発達するために精子形成期間を通じて持系 的に所要の脂質が与えられ, 徒つて小脂翼顆粒は増減l あるが SERTOLI 氏細胞中に常存するものと推定せら る。

豚は間質が最もよく発達するが，スダン亚染色，ナ， ル青染色拉よびオスミウム酸による 黒化陽性顆粒は； い。このことは間啠の発達している他動物に比して著 く矛盾を感ずるが SERTOL低細胞基底部に於いて直径; $10 \mu$ に達する大脂質顆粒がよく発達するため間睤に於 ては脂質どてて畒積する必要はないるのと考えられる、 天竺鼠では，精細管内脂質顆粒の分布は家鬼に類似す が，その数量は著しく少なく，また間質の発達も劣つ いる。そのために SERTOLI氏細胞基底部脂質顆粒の消. 期があり，脂質の装皘も大脂質顆粒の形成には至らな のであろうと解勫できる。大では間質が発達するにも かわらず大脂質顆粒があり，また消失期もある。しか 豚と巽なり間質の脂質は極めて多量であり，全間質が ダンIII可染顆粒でみたされ，腔側脂質の分布域拉よび 量は供試哺乳動物中，最高である。材料の採取がやや 殖季節をはずれているので精子形成力の強弱について べることはできないが, 腔側脂質より推定すれば,脂質 蓄積,消費は旺盛であると考えざるをえない。そのため 間質に多くの脂質顆粒があるが間質および細精管壁の 造なぞの影響により脂質顆粒の移動は急速に行い難く 費に伴つて供給が充分に行われないので SERTOLI氏細 
基底に大脂質顆粒をもつているが，またその消失期もせ ると考えられる。

以上，間質の発達度と脂質顆粒の消長の樣式について のべたが，これらの根柢にあつて，解決されねばならな い点は等丸組織の脉管外通液路の問題, 特に精細管蕉底 膜の構造であろ弓と考える。先に著者は大黒圂精細管基 底膜が扁平上皮椂細胞の一戸に配列せるものであり，そ の細胞間質の構密度扣よび小口が精子形成に半つて変化 し, 高分子物質, 粒子小よび諸種游走性細胞などを通過 せしめるものであり, したがつて間質の発達が劣つても 精細營内への物質移行は比較的念速に行われる 引のと推 定されると報告した。MontaGMa and Hamiton は人精 細管基底膜が 4 尸よりなることを報告している。特に犬 などの間質と細精管内脂誓顆粒の分布樣式は基底膜の構 造を明らかにしなければ解泎されないるのである。カナ へビ拉よびトノサマガェルでは精細管の精子形成像が哺 乳類と全く異なるために脂質顆粒の移動梯式を細分して のべることはできない。SERTOLI 氏細胞の行動について も殆んど明らかにされていないので，著者は鍍銀標本 と比較しつつ脂質顆粒が精子形成に伴つて消長を示すこ とを見たが，これらの動物の精子形成には季節的消長が あるのだ，年間全期の観察を行つていない限り詳細な報 告はなしえない。

フナの精子形成像はカナービおよびトノサマガェルに 等しいが，脂質顆粒の分布は全く異なる。精子形成全期 を通じ SERTOLr氏細胞内にのみ存し成熟精子とともに腔 内に脱落しない。すなわち精子が成熟すれば，これを包 囲しているSERTOLI氏細胞の連鎖は断たれ，両側に別れ 倩細管基底膜に向つて退き，次精子形成の始る汽，残留 青原細胞を创囲する。 フナのこれら脂質顆粒のスダン III，ナイル青およびオスミウム酸に対する態度は他の脊 倠動物之異なり，中性脂肪に近いるのである。したがつ て腔内に脱落しないこととともに，その機能的意義は高 学脊推動物とは余程異なつたものと考えねばならない。

\section{要 約}

（1）精細管内脂犋顆粒の精子形成に伴 5 移動は供試全 物に認められる。哺乳類拉よび鷄では脂買顆粒の移動 つほかに量的変化も珰めら的。これらにもとづいて5の 徵ある時期を区別することができる。

（2）SERTOLI 氏細胞基底脂質影粒は，牛，豚，家鬼扎よ :鶏では精子形成の全期間を通じて存在するが，天，天 : 鼠、大黑鼠および二十日瓦では，精子が腔内に游離す 時期には消失する。をた豚。大，大黒鼠および二十日

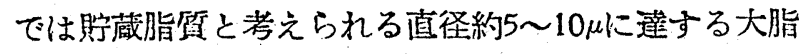

質顆粒を認めるが，牛，家鬼，天筷鼠および熖では大脂 質顆粒子浔めず，直径約 $1 \mu$ 小脂質顆粒が SERTOL低細 胞内に広く分布している。

すべてこれら顆粒の消長は間買の発達程度および基底 膜の構造の粗密の差巽と密接な関係がある。

（3）精細管内に見られる脂質顆粒の量は，動物種によ り差異があるようである。これは造精能力の強弱拉よび， 造精㥞式の差黑にもとづくのであろう。

（4）腔側脂睤顆粒は高等脊推動物では精子の游離:とと もに腔内に脱落するが、フナでは精子形成の全期間を通 じSERTOLI 氏細胞内のみにあつて，腔内に游離すること はない。フナでは精細管内脂質の性状は中性脂肪に近く， 精細胞の保護という附加的作用をるつと考えられる。

（5）分離細精管の連続切片の観察によれば, 大黒鼠精 子形成波の 6割は精子が形態形成を完了し腔内に游離す るむでの期間でしめられ SERTOLI氏細胞内脂質顆粒もこ の時期に減少し，消失する。精細胞の成熟拉よび精子の 形態完成を含むこの時期は，この細胞系列の物質代謝生 理上重要な意味をもつであろう。

（6）SERTOLI 氏細胞内脂買顆粒の精子形成に柈弓移動: そ量的変化はSERTOLI氏細胞の能動的生理活動を明膫に 示している。その脂啠は究㥛に㧊いて精細胞の成熟と精 子形成のエネルギー源として利用せられるものと思われ る。

稿をを措くに当り，終始御懇篤なる御指導と御校閲を 賜りました教室主任教授高木俊葴博士および名古屋大学 保田幹男助教授に対し，始に謹んで感謝の意を表し、ま た御高教を賜つた北海道大学教授牧野佐二郎搏士, 大阪 大学教授佐藤暂根博士，本学教授森田平治郎博士拉よび 一色於蒐四郎教授に厚く御礼申し上げる。

$$
\text { (1952. 12. 3. 受付) }
$$

\section{文 献}

(1) 野沢広行(1927)：実験医学 $11 ； 63$.

(2) Hugains, C., and Moudder, P. V. (19.5) : Cancer Research, 5, 510.

(3) CAlN, A. G., (1948) : Quart. J. Micr. Sci., 89, 429.

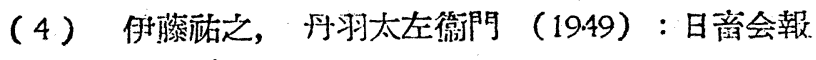
. $19,41$.

(5) W isLocki, G. B., (19.49): Endocrinol., 44, 167.

(6) Elftmann, H., (1950): Anat. Rec., 106, 381.

( 7 ) Perlman, P, S., (1950): Endocrinol., 46, 341.

(8) Howard, R.P., Smiffen, R. C., Simmons. 
F.A., and Albriger, F., (1950): Clinical. Endocrinol., 10, 121.

(9) Sniffen, R. C., (1950) : Arch.Path., 50, 259.

(10) Montagna. W. and Hammon, J. B. , (1951) : Anat. Rec., 109 : 635.

(11) $\nu$ (1952) : $\| \quad, 112.237$.

(12）西田隆雄 (1952) : 科学. 22, 475.

（13） $\nu （ \nu) ：$ 昭和27年度日本音産学会 秋季大会講演要旨.

(15) Maximow, A. and Bloom, W., (1947): A Text book of Histology. Pniladelphia.

\section{Résúmé}

Comparative studies on the migration and the quantitative changes of the lipid granules in testicular tissues accompanying the spermatogenetic wave were made in different classes of vertebrates and yielded the following results. The materials used in cluded the cattle, hogs, dogs, guinea pigs, rats, mice, the domestic fowl, $T a$ kydromus takydromoides (a lizard), Rana castebiana and Cyprinus auratus (a fish).

(1) The migration of the lipid granules in testicular tissues which accompanies the spermatogenesis is recognized in all the vertebrates investigated. In the mammals and tne domestic fowl, changes in their quantity are also marked besides the migration. On the basis of both these phenomena, five characteristic stages are distinguishable.

(2) In the cattle, hogs, rabbits and the domestic fowl, tne lipid granules in the basal part of SERTour cells persist through all the stages of the spermatogenesis, but in the dogs, guinea pigs, rats and mice, they disappear at the stage where the sperms become free in the lumen.

In hogs, doge, rats and mice, tne large lipid granules about $5 \mu$ to $10 \mu$ in diameter are found, which are believed to represent the reserve lipid. The large lipid granules do not exist in the cattle, rabbits, guinea pigs and the domestic fowl, but the small lipid granules about $1 \mu$ in diameter are distributed broadly in SERToLI cells.

This is related closely with the extent of development of the interstitial tissue and the differ- ence in the integrity of the basement membrane.

(3) That quantity of the lipid granules, which are found in seminiferous tubules seems to vary in different animals. This may be attributable to a difference either in the ability or in the mode of sperm production.

(4) In the land vertebrates, the lipid granules on the distal end of the Sertou cell get into the lumen at the same time as the sperms are freed therein, whereas in the Cyprinus auratus they remain within the confines of that cell through all the stages of the spermatogenesis and are never slougned into the lumen. The lipid in the seminiferous tubules of the latter resembles neutral fat in character and seems to prosses an additional function of protecting the spermatogenetic cells.

(5) In rats; it has been confirmed by observations on the serial sections of an isolated semi niferous tubule that about six tenths of one spermatogenetic wave represent the stage where the sperms are completely formed and freed into the lumen and the lipid granules in number and disappear eventually.

This time interval, during which the spermatogetic cells mature and complete the formation of the sperms, is believed to be of importance also to the physiology of metabolism of these cells.

(6) The migration and the quantitative changes of the lipid granules in Sertorr cells, which accompany the spermatogenesis indicate evidently active physiological activity on the part of SERTouI cells. The lipid may be considered to be expended eventually as energy source for maturation of the spermatogetic cells and the formation of the sperms. 


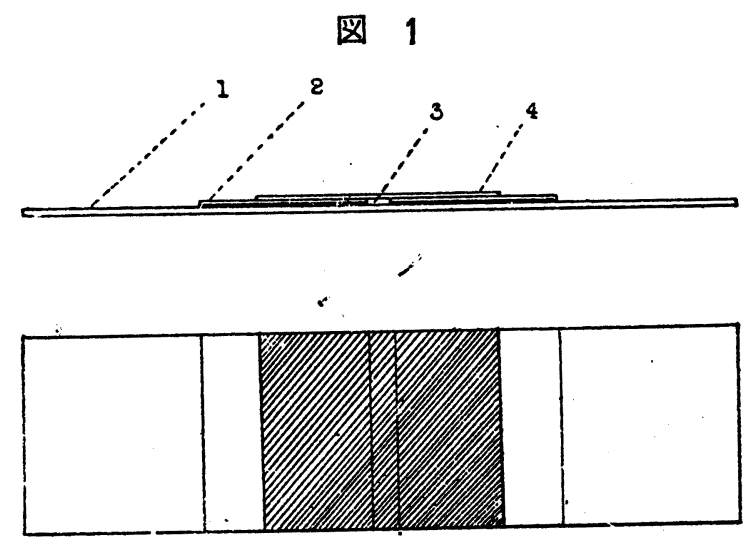

図 1 : 厚さ $1 \mathrm{~mm}$ 以下の戴せ硝子 (1) の上に被い硝子 を適当に切つて造つた 2 枚の硝子板 (2) を $3 \mathrm{~mm}$ の間隔 を保つて，バルサムではりつける。このようにして造つ た潅 (3) 一媒圈と分離細精管を大れ，被い硝子 (4)をし て，その両端をバラフインバルサムで封じ鏡検する。

附 図説 明

図 2〜3 CIACCIO 氏法により染色せられた大黒鼠粹丸組織内脂質顆粒。 $\times 200$

図 2 は精子形成第 2 期の精細管横断面で, SERTOLI 氏細胞基底部に脂質顆粒が認められる。

因 3 は第 4 期のもので SERTOI工氏細胞基底部脂質顆粒は著しく減じ，精子束間に小脂質顆粒の集塊が 認められる。

：図4～ $610 \%$ ホルマリン固定後，水結切片としスダン而染色法を施したるの。× 125

因，4は牛睪丸で SERTOLI氏細胞基底部の小脂質顆粒は多量で，かなり腔側にまで分布している。罒の 中央やや下の細精管は第1期より第2期への移行期で腔側には末だ脂質顆粒が現れていないが SERTOLI氏 細胞基底部の脂質顆粒は既に相当量に達している。

因 5 は豚睪丸で第 4 期の細精管, SERTOLI 氏細胞基底脂質顆粒は著しく発達している。

図6は大䅅丸で腔側に排出せられた脂質顆粒と間質内脂質とが極めて多量である。

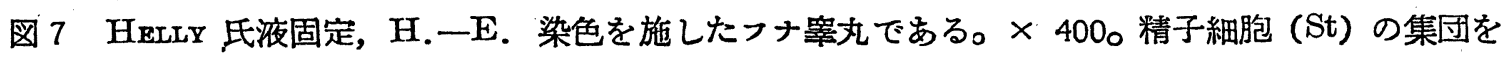
包囲していた SERTOLI 氏細胞は, 成熟精子 (S) の腟内へ游離せる後は基礎膜側に退行し, 残留精原細 胞 (Sg) を厚く包埋している。 